\title{
Molecular Mechanisms of Raccoon Rabies Virus Progression in Its Natural Host
}

\author{
Vythegi Srithayakumar1,2*, Hariharan Sribalachandran33, Rick Rosatte4, \\ Christopher J. Kyle ${ }^{2,5}$ \\ ${ }^{1}$ Trent University, West Bank Drive, Peterborough, Canada \\ ${ }^{2}$ Natural Resources DNA Profiling and Forensics Centre, Trent University, East Bank Drive, Peterborough, Canada \\ ${ }^{3}$ Biology Department, Trent University, West Bank Drive, Peterborough, Canada \\ ${ }^{4}$ Ontario Ministry of Natural Resources, Wildlife Research and Development Section, Trent University, East \\ Bank Drive, Peterborough, Canada \\ ${ }^{5}$ Forensic Science Department, Trent University, East Bank Drive, Peterborough, Canada \\ Email: *vythegisrithayakumar@trentu.ca
}

Received 22 October 2014; revised 28 November 2014; accepted 16 December 2014

Copyright (C) 2014 by authors and Scientific Research Publishing Inc.

This work is licensed under the Creative Commons Attribution International License (CC BY).

http://creativecommons.org/licenses/by/4.0/

(c) (i) Open Access

\begin{abstract}
Rabies virus presents a global public health problem. Our current understanding of the molecular determinants of rabies virulence stems from rodent models and laboratory strains of the virus, however, it is unclear how well rodent models represent viral response in natural reservoirs. Here, we examined interactions between the raccoon variant of rabies virus (RRV) and its natural host, raccoons, to gain a better understanding of molecular determinants of virulence in this system. We found expression patterns of RRV genes under tight control until the virus reached the central nervous system where replication increased significantly. Further, our examination of viral variants within an individual revealed that variant diversity may have an effect on virulence. We found that a mutation at a region of a $\mathrm{T}$ helper cell epitope on the nucleoprotein was associated with viral challenge outcomes and could be associated with RRV pathogenicity.
\end{abstract}

\section{Keywords}

Rabies, Raccoons, Innate Immune Response, Viral Expression, Quasispecies, Viral Variants

\section{Introduction}

Rabies viruses (RV) are part of the Lyssavirus genus and Rhabdoviridae family that are highly neurotropic, infecting mammals and almost invariably causing fatal encephalopathy [1]. RV consists of a negative-sense RNA

\footnotetext{
*Corresponding author.
}

How to cite this paper: Srithayakumar, V., Sribalachandran, H., Rosatte, R. and Kyle, C.J. (2014) Molecular Mechanisms of Raccoon Rabies Virus Progression in Its Natural Host. Advances in Microbiology, 4, 1222-1236. 
genome of about 12,000 bases which encodes five viral genes that include a nucleoprotein (N), phosphoprotein $(\mathrm{P})$, matrix protein $(\mathrm{M})$, glycoprotein $(\mathrm{G})$ and a large protein (L: RNA polymerase) [2]. Although significant advances have been made in rabies prevention and control, it continues to pose significant public health risks [3] [4]. In developing countries, more than 75,000 human deaths are attributed to this disease annually [5]. In North America, up to six human rabies cases were diagnosed per year; however, additional rabies cases likely go unrecognized as commonly undiagnosed acute and fatal neurologic illnesses (reviewed in [6]).

Rabies infection usually results from the bite of an infected animal and deposition of virus-laden saliva in the victim. The virus infects local sensory and motor neurons and then ascends to the brain by retrograde transport [7]-[9]. Uncontrolled replication of virus in the central nervous system (CNS) leads to disease and ultimately death. Despite the high lethality of RV, variation has been noted in the host's immune response and histopathological changes caused by the virus [10]-[14]; suggesting that factors governing the regulation of virulence of RV are diverse. Although rabies has been extensively studied over the past century, pathogenic mechanisms by which rabies infection results in neurological disease and causes death in natural reservoirs are not clear [15] [16] [18].

In an attempt to better understand RV mechanisms, and given the challenges associated with studying natural hosts, mouse models have been employed where several studies have shown that pathogenicity can be altered by amino acid substitutions in the RV genome [15]-[24]. While these studies have enhanced our understanding of the molecular determinants of RV pathogenicity, it is important to consider that responses observed in mice may not closely resemble natural conditions in rabies reservoirs and mice are dead-end hosts [25]. Further, the ability of RV to enter the CNS is one of its fundamental pathogenic characteristics [26]; however, the above mentioned studies evaluate virulence following intracerebral inoculation, which avoids the requirement of gaining access to the CNS. The culmination of these factors indicates that molecular determinants of RV pathogenicity described using mouse models and laboratory strains may only provide limited insights into mechanisms underlying the pathogenesis of RV with questionable significance for natural reservoirs.

In this study, we examined the interaction between the raccoon variant of rabies virus (RRV) and its natural reservoir host, the raccoon (Procyon lotor), to gain a better understanding of the molecular determinants of virulence in this system. RRV was first noted in Florida around the 1940s where it remained localized until the late 1970s when a second outbreak facilitated rapid spread along the eastern seaboard of North America [27]. High densities of raccoons in urban and suburban areas [28] [29] and the concomitant increase in potential human and pet exposures presented serious threats to human health [30]. Contrary to the common belief that exposure to rabies is always lethal, empirical studies have suggested that exposure of raccoons to RRV does not always result in clinical disease, perhaps due to differences in the properties of the virus [31] [32]. For example, $5 \%-40 \%$ of raccoons survived a RRV challenge [33] [31], the incubation period can vary among raccoons, and when vaccinated, the animals do not seroconvert evenly [34] [35]. The aforementioned observations illustrate variability in the disease outcome of raccoons after RRV exposure that may in some circumstances result in abortive infections.

In a previous study [16], we investigated the immune response elicited in raccoon hosts after infection with RRV and found that the innate immune system is triggered by RRV; further, changes in expression were correlated with the presence of viral RNA. Although similarities in response were present between this study and previously published studies using mouse models, differences were noted in both the timing and level of expression, highlighting the need to replicate these studies in natural reservoirs of rabies. In addition, there was variability in the immune response between different individuals indicating that the properties and variable interactions of the host and virus may play a crucial role in disease outcome. In this study, we focussed on the virus in order to gain additional insight into its role in infection by: 1) examining expression of viral genes following a peripheral RRV challenge, this allowed us to examine how expression patterns change with the progression of the disease; and 2) examining variants of the virus present within and among individuals to gain a better understanding of viral adaptation and potential determinants of pathogenicity. Overall, the objectives of this study were to enhance our understanding of the factors governing the regulation of virulence of RRV. Knowledge of the molecular determinants of rabies virulence is not only important for developing and refining post-exposure treatments, but also effective treatments once clinical disease has established.

\section{Materials and Methods}

Samples were obtained from a rabies challenge study performed by the Canadian Food Inspection Agency 
(CFIA) in conjunction with Ontario Ministry of Natural Resources (OMNR). The initial premise of the challenge experiment was to examine viral progression in raccoons after inoculation with RRV [32]. We obtained these samples from the CFIA and performed RNA extraction from previously collected tissues to perform the experiment described herein.

\subsection{Challenge Study}

Twenty-two wild raccoons were captured by OMNR staff in southern Ontario from regions that had not been exposed to RRV (lack of prior exposure to rabies was confirmed through serology tests). These animals were transported to a biocontainment level 3 animal care facility at the CFIA, in Nepean Ontario where the challenge study was conducted. All animal experimentation was performed according to the guidelines of the Canadian Council on Animal Care with the approval of the institute's animal care committee. Additional details of the challenge study are taken from the doctoral thesis of Szanto [32].

\subsection{Virus Preparation and Experimental Design}

RRV stock was propagated in murine neuroblastoma cells as previously described by Szanto [32]. Two raccoons were euthanized four days prior to the start of the experiment to serve as negative controls. Twenty raccoons were inoculated into the right hind leg muscle with $0.5 \mathrm{ml}$ of virus stock $\left(10^{6.7} \mathrm{TCID}_{50}\right)$. Raccoons were housed individually and monitored daily for clinical signs of rabies. Two raccoons on each of 2, 4, 8, 15 and 32 days post infection (dpi) were chosen at random and euthanized (test group of 10 animals). The remaining 10 animals were kept under observation until they exhibited clinical signs of rabies, at which point they were euthanized. Within this group six animals were euthanized at days 20, 21, and 23; the remaining four animals did not exhibit any clinical signs of the disease, but were euthanized at the end of the experiment on day 533 pi. Tissues collected from all animals included: muscle tissue from the inoculated right leg muscle, a section of lumbar spinal cord, cerebral cortex and salivary gland. Samples were immediately frozen and stored at $-80^{\circ} \mathrm{C}$ until use.

\subsection{Gene Assay Design}

Taqman probes to target each individual RRV gene were designed using Custom TaqMan ${ }^{\circledR}$ Expression Assays using previously published RRV genome as the template (GenBank accession \# EU311738; Applied Biosystems; Table 1).

\subsection{RNA Extraction}

Total RNA was extracted from all samples using TRIzol (Invitrogen) following the manufacturer's standard protocol. Precipitated RNA was dissolved in $50 \mu \mathrm{l}$ of DEPC-treated water and quantified using a NanoDrop ${ }^{\mathrm{TM}}$ 8000 (Thermo Scientific) spectrophotometer. DNA was removed by treatment with Turbo DNase enzyme (Applied Biosystems) following the manufacturer's protocol. RNA quality and quantity was assessed using gel electrophoresis and the NanoDrop ${ }^{\mathrm{TM}} 8000$ (Thermo Scientific) spectrophotometer.

\subsection{DNA Contamination Assessment}

DNA contamination was assessed through attempted amplification of mitochondrial DNA cytochrome $b$ gene (4680F-TGACTTGAARAACCAYCGTTG; 4682R-CCCTCAGAATGATATTTGTCCTCA). PCR was prepared with components in the following concentrations: 1X PCR buffer (Invitrogen), $0.2 \mathrm{mM}$ of each dNTP, 1.5 $\mathrm{mM} \mathrm{MgCl}_{2}, 0.2 \mu \mathrm{M}$ of forward primer, $0.2 \mu \mathrm{M}$ of reverse primer, $0.6 \mathrm{U}$ of Taq DNA polymerase (Invitrogen), $10 \mathrm{ng}$ of RNA and $\mathrm{ddH}_{2} \mathrm{O}$ as needed for a total volume of $12 \mu \mathrm{l}$. Amplification conditions were as follows: initial denaturation at $94^{\circ} \mathrm{C}$ for $5 \mathrm{~min}$; [denaturation at $94^{\circ} \mathrm{C}$ for $30 \mathrm{sec}$, annealing at $55^{\circ} \mathrm{C}$ for $1 \mathrm{~min}$, extension at $72^{\circ} \mathrm{C}$ for $\left.1 \mathrm{~min}\right] \times 35$ cycles; final extension at $60^{\circ} \mathrm{C}$ for $45 \mathrm{~min}$; and $4^{\circ} \mathrm{C}$ hold. $2 \mu \mathrm{l}$ of the reaction was subjected to agarose gel electrophoresis to assess DNA contamination.

\subsection{Reverse Transcription and Expression Analysis}

To determine the expression levels of the selected genes, RT-qPCR was performed on RNA extracts. $1 \mu \mathrm{l}$ of purified RNA was used in a $20 \mu \mathrm{l}$ reverse transcription reaction using High Capacity reverse transcriptase en- 
Table 1. Primers and Taqman probes used in this study.

\begin{tabular}{|c|c|c|c|}
\hline Transcript & Primer & Sequence & $\mathrm{Tm}$ \\
\hline \multirow[t]{3}{*}{ RRV-N } & Forward & CGGTATGAATGCAGCTAA & \\
\hline & Reverse & CCAGTTCССТTCTACATC & \\
\hline & Probe $^{*}$ & TGCTCTTACTTGGC & \\
\hline \multirow[t]{3}{*}{ RRV-P } & Forward & CAGAGGAGACTGTAGATC & \\
\hline & Reverse & GGCAGACTATCTACTTCTATA & \\
\hline & Probe $^{*}$ & AGGACAATCAGGCTCATC & \\
\hline \multirow[t]{3}{*}{ RRV-M } & Forward & TGGGTTTACAAACTAAGGA & \\
\hline & Reverse & CCAGATTCTACCTTGGATA & \\
\hline & Probe $^{*}$ & TGTCTAGCACTCAC & \\
\hline \multirow[t]{3}{*}{ RRV-G } & Forward & CTTCGTTGTGTTTTGGGA & \\
\hline & Reverse & CTGAGATGATGTATGTCGATA & \\
\hline & Probe $^{*}$ & CTACACAATACCAGACAAG & \\
\hline \multirow[t]{3}{*}{ RRV-L } & Forward & AGGGACTTTCTGCTTATG & \\
\hline & Reverse & CAAGGTAAACTATTCTAGACATAG & \\
\hline & Probe $^{*}$ & CATCAGCACTCAGTAT & \\
\hline \multirow[t]{2}{*}{ RRV-N1 } & Forward & CTCCCTGGGAAAAGCTCCTG & $60^{\circ}$ \\
\hline & Reverse & GAACACGTGACCAACTGCAC & $57^{\circ}$ \\
\hline \multirow[t]{2}{*}{ RRV-N2 } & Forward & AGGGATCCCACCATTCCAGA & $55^{\circ}$ \\
\hline & Reverse & TGAATTGGGGCGAGCTTGAT & $53^{\circ}$ \\
\hline \multirow[t]{2}{*}{ RRV-G1 } & Forward & TTGTTGTGGAAGACGAGGGG & $59^{\circ}$ \\
\hline & Reverse & TGTCACAAGATGTCCCGAGC & $60^{\circ}$ \\
\hline \multirow[t]{2}{*}{ RRV-G3 } & Forward & GGGGAAATGCACGGGTCTAA & $59^{\circ}$ \\
\hline & Reverse & GAACGGACTTGTAGTGGGCA & $60^{\circ}$ \\
\hline \multirow[t]{2}{*}{ RRV-G3b } & Forward & GTTCGGACTTGGAGCGAGAT & $59^{\circ}$ \\
\hline & Reverse & GAGCATAGTGTGTGGAGGGG & $59^{\circ}$ \\
\hline \multirow[t]{2}{*}{ RRV-G2a } & Forward & CCTGGGTTTGGGAAGGCATA & $59^{\circ}$ \\
\hline & Reverse & ATGATCTCGCTCCAAGTCCG & $59^{\circ}$ \\
\hline
\end{tabular}

"Probes were labelled with FAM at 5' and NFQ at 3'.

zyme (Applied Biosystems) following the manufacturer's protocol. Gene specific primers listed in Table 1 were used to prime cDNA synthesis. TaqMan ${ }^{\circledR}$ PCR was performed on a Step One Plus ${ }^{\mathrm{TM}}$ instrument, using TaqMan ${ }^{\circledR}$ Fast Universal PCR Master Mix (Applied Biosystems) according to the manufacturer's conditions. All experimental samples contained at least three technical replicates with no template controls. The transcripts of $\mathrm{N}$ gene were normalized against $\beta$-actin; whereas the other four viral genes were normalized against $\mathrm{N}$ gene and expression levels were calculated using the $2^{-\Delta \Delta \mathrm{Ct}}$ method [36]. Statistical significance was determined by student's t-test, with P-values of $<0.05$ considered statistically significant.

\subsection{Clonal Sequencing}

RNA from the brain of a raccoon that showed clinical symptoms after the challenge was utilized (sample $20+2$; see Table 2) to prepare a cDNA library for clonal, next generation sequencing. Approximately, one $\mu \mathrm{g}$ of RNA was used to prepare cDNA using the Ovation RNA-Seq system (Nugen) following the manufacturer's protocol. 
Table 2. Time course of RRV infection in raccoons.

\begin{tabular}{|c|c|c|c|c|c|c|}
\hline Sample & Days Post inoculation & Clinical signs & Site of inoculation ${ }^{\mathrm{a}}$ & Spinal Cord ${ }^{\mathrm{a}}$ & Brain $^{a}$ & Salivary glands ${ }^{\mathrm{a}}$ \\
\hline Control 1 & -4 & - & - & - & - & - \\
\hline Control 2 & -4 & - & - & - & - & - \\
\hline $2+1$ & 2 & - & - & - & - & - \\
\hline $2+2$ & 2 & - & - & - & - & - \\
\hline $4+1$ & 4 & - & - & - & - & - \\
\hline $4+2$ & 4 & - & - & - & - & - \\
\hline $8+1$ & 8 & - & + & + & + & - \\
\hline $8+2$ & 8 & - & - & - & - & - \\
\hline $15+1$ & 15 & - & - & - & - & - \\
\hline $15+2$ & 15 & - & - & - & - & - \\
\hline $20+1$ & 20 & + & - & + & + & - \\
\hline $20+2$ & 20 & + & - & + & + & - \\
\hline $21+1$ & 21 & + & - & + & + & + \\
\hline $22+1$ & 22 & + & + & + & + & + \\
\hline $23+1$ & 23 & + & - & + & + & - \\
\hline $23+2$ & 23 & + & - & + & + & - \\
\hline $32+1$ & 32 & - & - & - & - & - \\
\hline $32+2$ & 32 & - & - & - & - & - \\
\hline $533+1$ & 533 & - & - & - & - & - \\
\hline $533+2$ & 533 & - & - & - & + & - \\
\hline $533+3$ & 533 & - & - & - & - & - \\
\hline $533+4$ & 533 & - & - & - & - & - \\
\hline
\end{tabular}

${ }^{\mathrm{a}}$ Viral RNA detected by qPCR $<45$ CT.

Amplified cDNA was purified using a QIAquick PCR Purification Kit (Qiagen) as per the manufacturer's instructions. The cDNA library was prepared using protocols described by a Roche Diagnostics application note published on their webpage (Roche Diagnostics). The resulting cDNA library was sequenced using 454 pyrosequencing on a Roche GS Junior platform following the manufacturer's instructions. The bioinformatics were performed on GS De Novo Assembler and GS Reference Mapper (Roche) using previously published RRV genome (GenBank accession \#EU311738) as reference.

\subsection{Amplification and Sanger Sequencing of N and G RRV Genes}

The RRV nucleoprotein and glycoprotein were amplified in the samples that the virus was detected in using primers outlined in Table 1. PCR was prepared with components in the following concentrations: 1X PCR buffer (Invitrogen), $0.2 \mathrm{mM}$ of each dNTP, $1.5 \mathrm{mM} \mathrm{MgCl}_{2}, 0.2 \mu \mathrm{M}$ of forward primer, $0.2 \mu \mathrm{M}$ of reverse primer, $0.6 \mathrm{U}$ of Taq DNA polymerase (Invitrogen), $10 \mathrm{ng}$ of cDNA and $\mathrm{ddH}_{2} \mathrm{O}$ as needed for a total volume of $12 \mu \mathrm{l}$. Amplification conditions were as follows: initial denaturation at $94^{\circ} \mathrm{C}$ for $5 \mathrm{~min}$; [denaturation at $94^{\circ} \mathrm{C}$ for $30 \mathrm{sec}$, annealing at temperatures listed in Table 2, for $1 \mathrm{~min}$, extension at $72^{\circ} \mathrm{C}$ for $\left.1 \mathrm{~min}\right] \times 35$ cycles; final extension at $60^{\circ} \mathrm{C}$ for $45 \mathrm{~min}$; and $4^{\circ} \mathrm{C}$ hold. $2 \mu \mathrm{l}$ of the reaction was subjected to agarose gel electrophoresis to visualize the fragment amplification. PCR products were purified using ExoSAP (NEB) following the manufacturer's instructions. Amplicons were sequenced in both directions using BigDye ${ }^{\circledR}$ Terminator v3.1 Cycle Sequencing Kit (ABI). Sequenced PCR products were ethanol precipitated, then electrophoresed and visualized on an ABITM 3730 DNA Analyser. Sequences were edited and aligned to the RRV genome (GenBank accession \#EU311738) 
using MEGA ${ }^{\mathrm{TM}} 4.1$ [37].

\subsection{Structural Bioinformatics}

Structure of RV was obtained from the RCSB protein databank (2GTT). Structural predictions were performed on a SWISS-MODEL using automated mode for both the wildtype and mutant [38] [39]. The structural stability was assessed on SDM (a server for predicting effects of mutations on protein stability and malfunction: [40]).

\section{Results}

\subsection{Viral Detection}

At the site of inoculation viral RNA was detected in two of raccoons, one that showed clinical symptoms, and another that was euthanized at 8 dpi (Table 2).Viral RNA was not present in the lymph nodes of any of the samples. RRV was detected in spinal cords of all the animals that showed clinical symptoms and in one of the raccoons that was euthanized at 8 dpi. Viral RNA was detected in the brains of eight raccoons after the peripheral inoculation (Table 2). Viral RNA was found in all the samples that showed clinical symptoms, it was also detected in a racoon that was euthanized at eight days and it was also present in a one raccoon which survived the experiment (euthanized 533 dpi. with no symptoms of RRV: Table 2). RRV was also detected in the salivary glands of two the samples that showed clinical symptoms (Table 2). All results described herein focus only on samples in which viral RNA was detected.

\subsection{Viral Expression}

All five genes were detected in two samples at the site of inoculation, a sample euthanized at eight days and a sample that showed clinical symptoms at 22 dpi (Figure 1(a); not statistically significant). All five viral genes were expressed at the spinal cord in seven of the raccoons. Transcripts of $\mathrm{P}$ gene were higher than $\mathrm{N}$ gene in all the samples (Figure 1(b)), and transcripts of G and L genes were lower (8 and 66 fold, respectively) compared to $\mathrm{N}$ gene (Figure 1(b)). The levels of transcripts were similar between the animal that was euthanized at 8 dpi and the animals that showed clinical symptoms. At the cerebral cortex, N, P and M genes were expressed in a sequential manner in the samples (Figure 1(c)). Transcripts of $\mathrm{G}$ and $\mathrm{L}$ genes were only detected in the raccoon that was euthanized at $8 \mathrm{dpi}$ and all the animals that exhibited clinical symptoms from 20 - 24 dpi; they were not detected in the animals that survived the challenge $(533+2)$. Levels of transcripts were similar in the individual that was euthanized at $8 \mathrm{dpi}$ and samples that showed clinical symptoms with the exception of $\mathrm{M}$ gene, which was expressed at higher levels in the samples that showed clinical symptoms (Figure 1(c)). Although N, P and $\mathrm{M}$ were present in the sample that survived the challenge $(533+2)$, the transcripts of these genes were much lower when compared to other samples.

Expression patterns of viral genes were examined temporally within an individual $22 \mathrm{dpi}(22+1)$. At the site of inoculation the $\mathrm{N}$ and $\mathrm{P}$ genes were barely detectable $\left(2^{-\Delta \Delta \mathrm{Ct}}<0.05\right.$; Figure 2$)$. Transcripts of all five genes increased at the spinal cord and cerebral cortex, however transcript levels of $\mathrm{N}, \mathrm{P}$ and $\mathrm{M}$ were higher in the spinal cord compared to the cerebral cortex. In contrast, the level of expression of $G$ and $L$ genes increased in the cerebral cortex when compared to the spinal cord. From the salivary gland samples, only the $\mathrm{N}$ gene was detected at very low levels (data not shown).

\subsection{Genetic Variation within an Individual}

Next generation, clonal sequencing was employed to assess viral variants present within a single rabid raccoon. From a single run on the 454 GS Junior (Roche) platform we recovered 15,800 reads that were mapped to the reference RRV sequence (GenBank accession \#EU311738) providing $150 \times$ coverage of the virus. When compared to the reference RRV sequence, 42 variable sites were found, with 17 synonymous substitutions and 26 non-synonymous substitutions (Table 3 ). The $\mathrm{N}$ gene had the greatest amount of diversity ( $0.51 \%$ ), with 7 variable sites, 4 synonymous substitutions and 3 non-synonymous substitutions. Four variable sites were present at the P gene $(0.44 \%)$ with 1 synonymous substitution and 3 non-synonymous substitutions. M gene had 2 variable sites $(0.32 \%)$ with both of them being non-synonymous substitutions. The G gene had the least amount of diversity $(0.12 \%)$ with 2 variable sites (both synonymous substitutions). The L gene had 26 variable sites (0.41\%), 


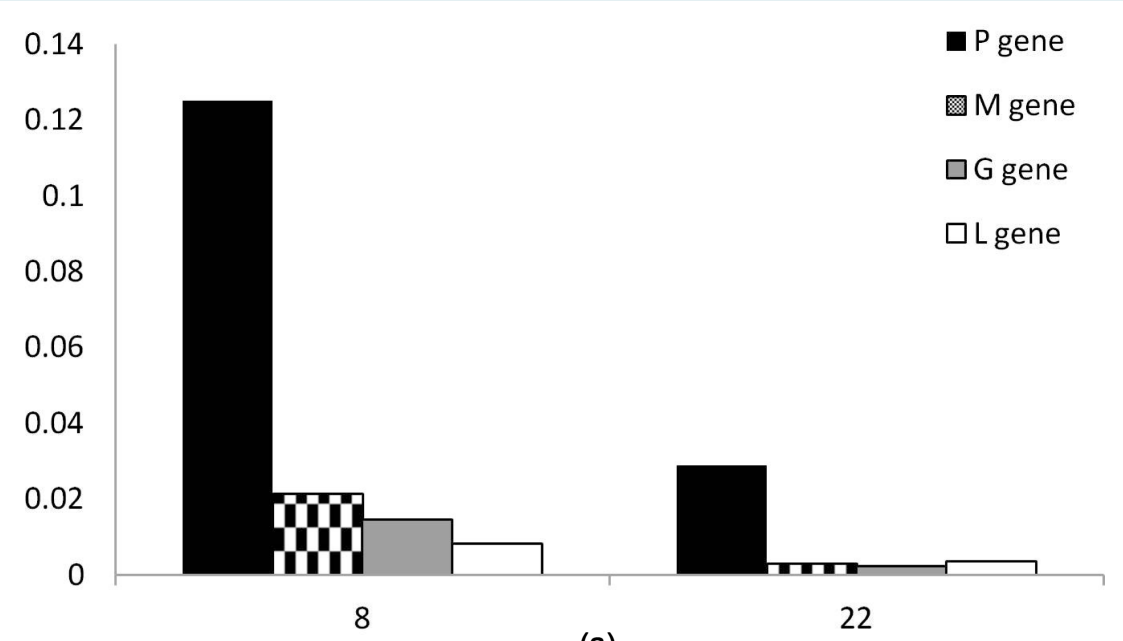

(a)
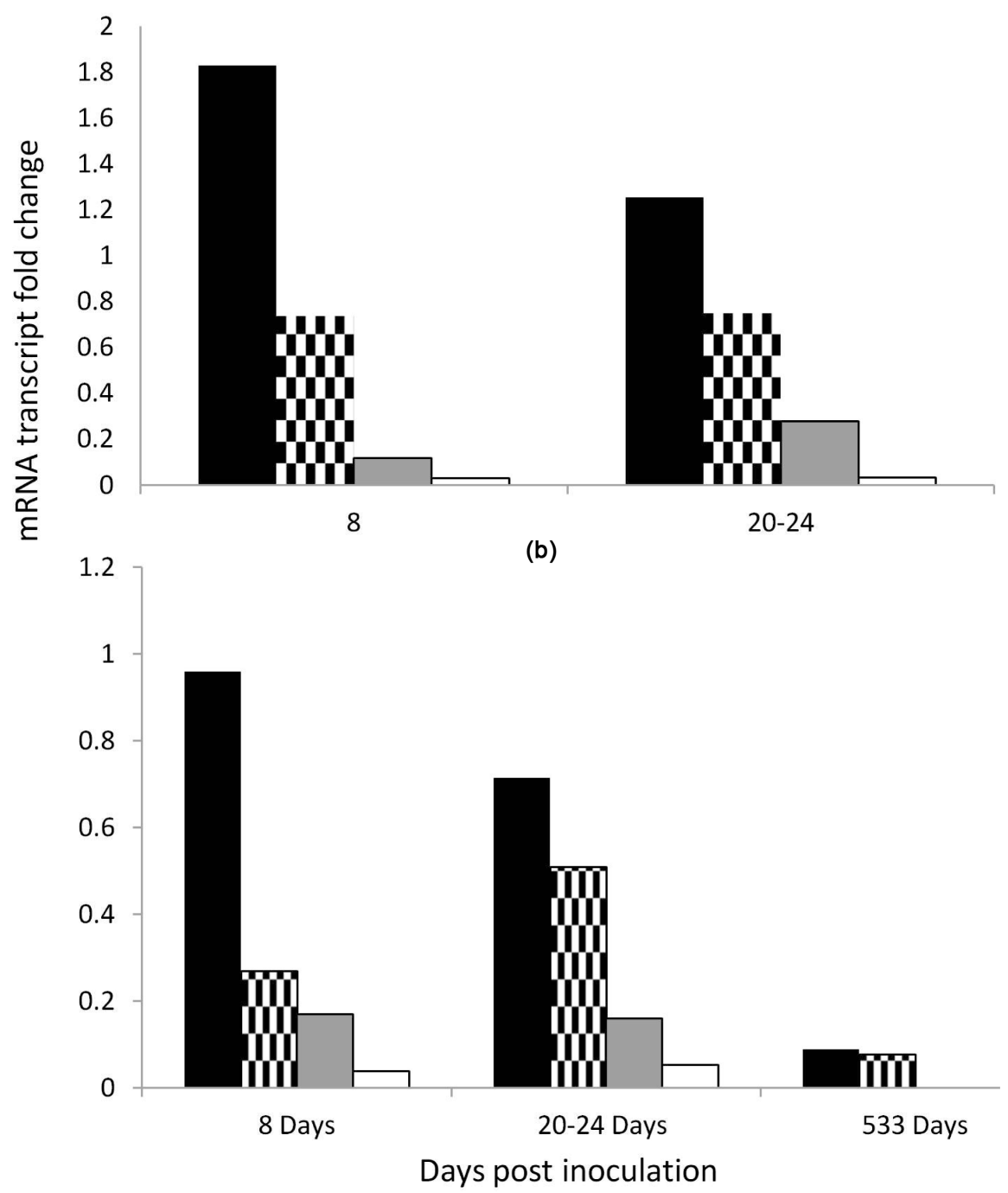

(c)

Figure 1. Viral expression following peripheral injection with RRV within raccoons in (a) site of inoculation, (b) spinal cord and (c) cerebral cortex Results are expressed as fold change when calibrated to the control with actin and viral nucleoprotein as the normalizer. 


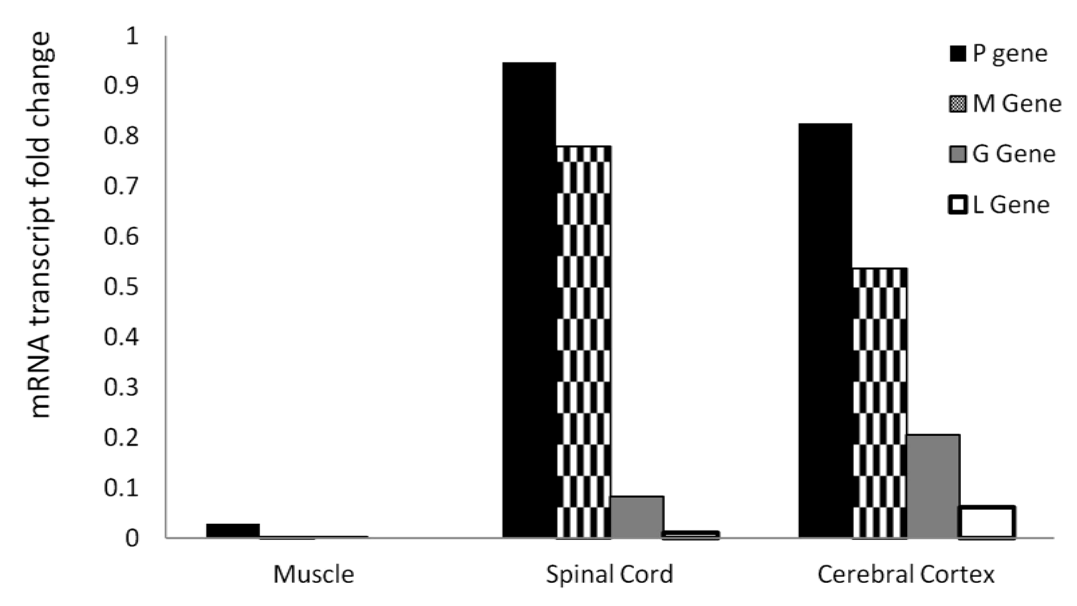

Figure 2. Viral expression following peripheral injection with RRV within raccoons 22 days post inoculation. Results are expressed as fold change when calibrated to the control with actin and viral nucleoprotein as the normalizer.

with 8 synonymous substitutions and 18 non-synonymous substitutions.

\subsection{Genetic Variation among Individuals}

$\mathrm{N}$ and $\mathrm{G}$ genes were amplified in all the samples that RRV was detected in. In the $\mathrm{N}$ gene, there was one non-synonymous substitution at position 412 in the all the samples that showed clinical symptoms of RRV (Figure 3). This variation was not present in the raccoon euthanized at 8 dpi or the animal that showed no symptoms for 533 dpi. Although the G gene was amplified and sequenced in all the samples that RRV was detected in, there were no variable sites present.

\section{Discussion}

Rabies (RV) virus presents a global public health problem. While dogs are the major reservoirs of RV in developing countries, a wide array of wildlife species pose threats in North America, including raccoons, skunks, foxes and bats [3] [4] [41]. It is therefore important to understand the pathogenesis of this disease as this knowledge assists with the development and refinement of tools to mitigate such threats. To date, several studies have elucidated molecular determinants of RV virulence using mouse models and laboratory fixed strains of the virus [15] [16] [18]-[21] [23] [24]. Although these studies have been informative, it is important to acknowledge that mice are dead end hosts to RV, and as such, responses to this disease may be different in natural reservoirs. In this study, we examined the role of the virus following peripheral inoculation with the raccoon strain of RV (RRV) in its natural host, raccoons, with the objective of enhancing our understanding of factors governing the regulation of pathogenicity in RRV. Our findings indicate that viral expression is kept under tight control until the virus reaches the central nervous system of the host. When examining the viral diversity within and among raccoons, results suggest that a site located on the T helper cell epitope may have an influence on the virulence.

\subsection{Viral Expression}

We have shown that RRV genes are expressed in a sequential manner in the challenge study samples (Figure 1). Rabies is a slow replicating virus that aims to preserve host cell function and relies on other mechanisms, rather than speed alone, to overcome host defences [42]-[44]. Our results corroborate previous findings where expression of viral genes increased with progression of disease (Figure 1). Several studies have illustrated that glycoprotein is a major contributor to rabies pathogenicity, and one of the identified mechanisms using mouse models is the tight regulation of glycoprotein expression [45]-[47]. In line with these findings, our study found expression of glycoprotein was minimal until the virus reached the cerebral cortex. This low expression may prevent apoptosis by maintaining structural integrity of neurons and enabling the virus to reach the CNS [17] [46].

Clinical outcome of viral infection depends on the balance between viral replication and host response. At- 
Table 3. Viral diversity in the cerebral cortex of a raccoons 22 days after inoculation with RRV.

\begin{tabular}{|c|c|c|c|c|c|}
\hline Viral Protein & Nucleotide Position & Reference & Variant & Total Variation (\%) & Type of Change \\
\hline Nucleoprotien & 286 & $\mathrm{~T}$ & C & 100 & Synonymous \\
\hline Nucleoprotien & 769 & $\mathrm{C}$ & $\mathrm{T}$ & 100 & Synonymous \\
\hline Nucleoprotien & 793 & $\mathrm{C}$ & $\mathrm{T}$ & 100 & Synonymous \\
\hline Nucleoprotien & 830 & $\mathrm{C}$ & A & 100 & Non-synonymous \\
\hline Nucleoprotien & 1124 & $\mathrm{C}$ & A & 94.9 & Non-synonymous \\
\hline Nucleoprotien & 1180 & A & G & 97.8 & Synonymous \\
\hline Nucleoprotien & 1304 & $\mathrm{C}$ & A & 98.8 & Non-synonymous \\
\hline Phosphoprotein & 1597 & $\mathrm{~T}$ & C & 100 & Synonymous \\
\hline Phosphoprotein & 2092 & $\mathrm{C}$ & A & 100 & Non-synonymous \\
\hline Phosphoprotein & 2166 & G & A & 10.8 & Non-synonymous \\
\hline Phosphoprotein & 2168 & $\mathrm{~T}$ & A & 10.8 & Non-synonymous \\
\hline Matrix protein & 2923 & G & C & 100 & Non-synonymous \\
\hline Matrix protein & 2924 & G & C & 100 & Non-synonymous \\
\hline Glycoprotein & 3933 & A & C & 100 & Synonymous \\
\hline Glycoprotein & 4590 & $\mathrm{~T}$ & C & 88.6 & Synonymous \\
\hline Intraregion & 5138 & G & A & 96.2 & Non-synonymous \\
\hline Large Protein & 7481 & G & A & 98.4 & Synonymous \\
\hline Large Protein & 8662 & $\mathrm{C}$ & A & 80 & Non-synonymous \\
\hline Large Protein & 8810 & $\mathrm{C}$ & $\mathrm{T}$ & 100 & Synonymous \\
\hline Large Protein & 9087 & G & C & 100 & Non-synonymous \\
\hline Large Protein & 9100 & G & C & 97.4 & Non-synonymous \\
\hline Large Protein & 9173 & $\mathrm{C}$ & $\mathrm{T}$ & 100 & Synonymous \\
\hline Large Protein & 9227 & G & C & 100 & Non-synonymous \\
\hline Large Protein & 9250 & G & A & 88.5 & Non-synonymous \\
\hline Large Protein & 9271 & G & $\mathrm{T}$ & 100 & Non-synonymous \\
\hline Large Protein & 10,244 & A & G & 98.4 & Synonymous \\
\hline Large Protein & 10,721 & A & G & 10.2 & Non-synonymous \\
\hline Large Protein & 10,722 & A & G & 10.2 & Non-synonymous \\
\hline Large Protein & 10,744 & A & G & 10.7 & Non-synonymous \\
\hline Large Protein & 10,816 & G & $\mathrm{T}$ & 100 & Non-synonymous \\
\hline Large Protein & 10,817 & G & $\mathrm{C}$ & 100 & Non-synonymous \\
\hline Large Protein & 10,826 & $\mathrm{C}$ & $\mathrm{T}$ & 97.9 & Synonymous \\
\hline Large Protein & 10,835 & G & A & 100 & Non-synonymous \\
\hline Large Protein & 10,837 & $\mathrm{~T}$ & C & 100 & Non-synonymous \\
\hline Large Protein & 10,844 & G & $\mathrm{C}$ & 95.7 & Synonymous \\
\hline Large Protein & 10,845 & $\mathrm{~T}$ & A & 91.3 & Non-synonymous \\
\hline Large Protein & 10,849 & $\mathrm{~T}$ & C & 89.5 & Non-synonymous \\
\hline Large Protein & 10,859 & G & A & 98.5 & Synonymous \\
\hline Large Protein & 10,865 & G & A & 95.6 & Synonymous \\
\hline Large Protein & 10,871 & G & $\mathrm{C}$ & 100 & Non-synonymous \\
\hline Large Protein & 10,874 & $\mathrm{~T}$ & G & 94.7 & Non-synonymous \\
\hline Large Protein & 10,872 & $\mathrm{C}$ & G & 93.9 & Non-synonymous \\
\hline
\end{tabular}

${ }^{\mathrm{a}}$ Indicates the percentage of the sequences that contains the variant. 


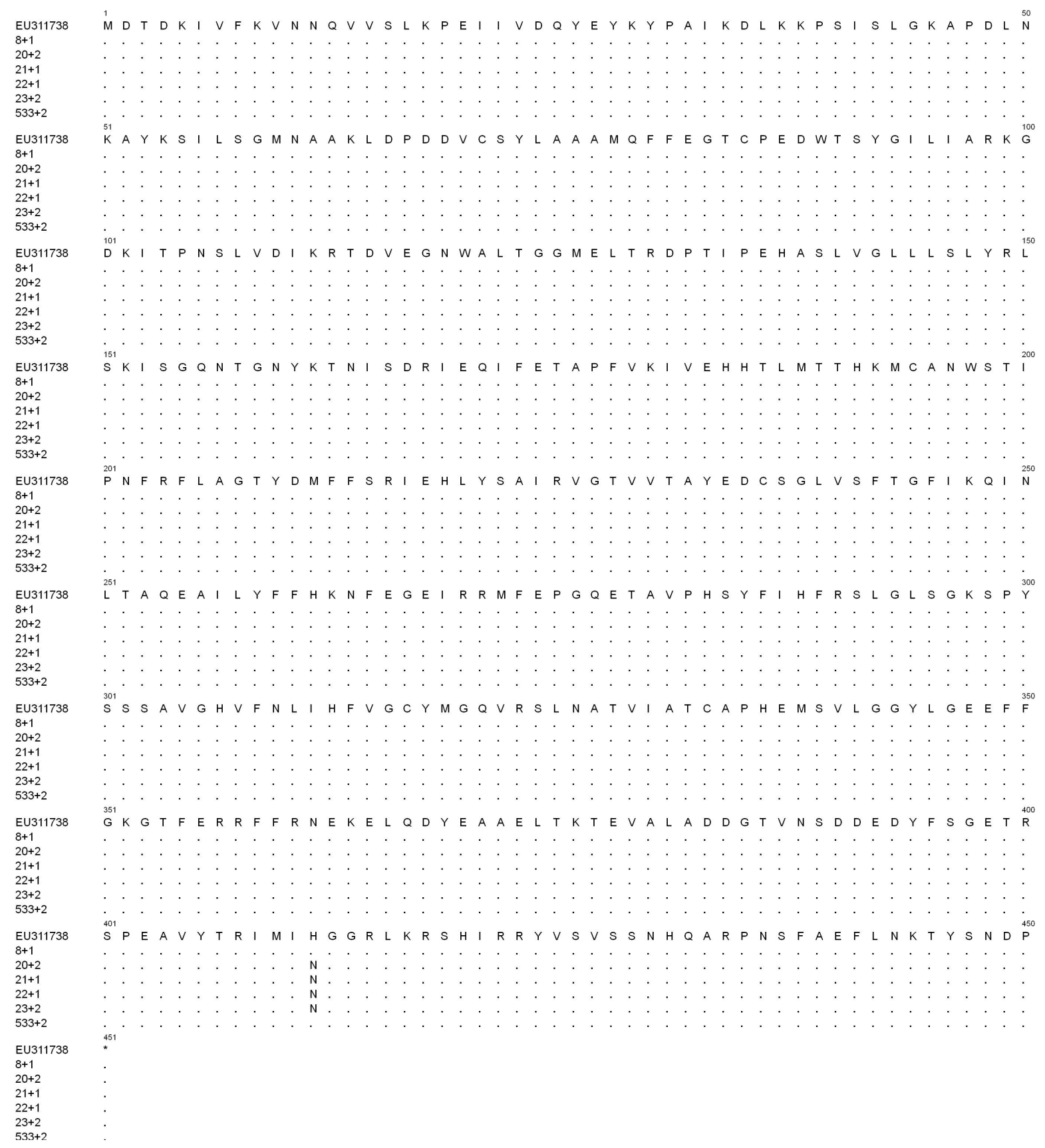

Figure 3. Protein sequences rabies nucleoprotein. Amino acid numbers are shown above the reference raccoon rabies virus (EU311738). Identity to the reference is indicated by dots, whereas the differences are specified by letter substitutions.

tenuation of rabies is usually correlated with increased replication and transcription, as well as activation of the immune response in the host [43] [45]-[47]. In one of the samples that that was euthanized at eight dpi, viral genes were expressed at similar levels to samples that showed clinical symptoms between 20 - 24 dpi. This suggests that the virus may have been attenuated in this particular sample, hence the increased replication and transcription that was observed. It is interesting to note that genes associated with the interferon pathway, as well as inflammatory cytokines, and viral receptors were also expressed in this particular sample [14]. When comparing results of this study, to Srithayakumar et al. [14], it is evident that the presence of the virus was vital for the initiation of the immune response. In this study, we found viral genes to be expressed at low levels at the site of inoculation in two of the samples (Figure 1(a)), however in the same samples the earliest time point to detect 
the genes indicative of the innate immune response was in the spinal cord and brain. From the expression patterns noted in this study, and the immune response data obtained from Srithayakumar et al. [14], there is a weak correlation between the expression of glycoprotein and the initiation of the immune response.

\subsection{Viral Variants}

All raccoons in this study were infected with the same stock of RRV; however, variability was noted in both viral expression and immune response between samples. Although host genetic factors may have contributed to these differences, genetic properties of the virus will also have an impact. Given the short generation time and high mutation rates of RNA viruses, viral populations are not comprised of a single variant, but rather a complex of non-identical variants termed, quasispecies [48]-[50]. These variants provide an adaptive advantage in new environments and challenges during infection [48]-[50]. We examined the quasispecies present within an individual using next generation sequencing technology, which allowed for in depth sequencing of the variants present with a 150× coverage of the genome. A study by Khawplod et al. [51], examined the diversity of rabies at two fragments of glycoprotein using cloning and Sanger sequencing (653 bp and 1056 bp, respectively). Khawplod et al. [51] found that from within a single rabid dog [51], there were 57 base substitutions at the 1700 bp region analyzed, whereas we only found 42 variable sites within the whole genome of RRV, with only two synonymous substitutions at the glycoprotein (Table 3). Although several factors such as high PCR cycles and artifacts inherent to clonal methods may have introduced artificial variants, the number of substitutions we found is still much lower in comparison. The amount of time the virus was replicating within an individual will also have an effect on the amount of variability. For the sample utilized in the present study time of replication was less than 22 days (given that the sample was euthanized $22 \mathrm{dpi}$ ), whereas the duration of rabies prior to death is not known for the sample utilized by Khawplod et al. [51], suggesting that the duration of replicating virus may have contributed to the number of mutations.

Although the number of mutations we found was low compared to Khawplod et al. [51], that may not have had an impact on the virulence of RRV. Vignuzzi et al. [52] examined quasispecies diversity in poliovirus and found that the greater amount of sequence diversity present within the viral subpopulation does not enhance virulence. Instead they suggest a more complex model where there is a positive interaction between the variants within the population, with different variants having advantages at different stages of infection. For example, certain variants may facilitate viral replication at local neurons, whereas another set of variants may be advantages in the axonal transport, another set of variants may have a role in evading the host's immune system, and yet another subpopulation of the virus may facilitate entry to the CNS. Therefore, maintaining the complex quasispecies enables the virus to spread systematically by complementing functions of the different viral variants to successfully infect the host, suggesting quasispecies diversity, rather than individual mutations, enhances pathogenicity [52]. Having too many mutations in the genome can lead the population to viral extinction; whereas, having few variants create "bottlenecks", rendering the virus unable to adapt to changing environments, such as replication in different tissues [52] [53]. These findings suggest that viral mutation is fine-tuned and optimized during the evolution of the virus, which facilitates adaptation to changing environments while maintaining the number of optimal variants.

In order to assess the functionality of the variants present within an individual we examined if any of the variable sites overlapped with any known catalytic domains of RV. Of the 42 variable sites, only one site on the nucleoprotein (Pos. 412) was located on a T helper cell (Th) epitope [54]-[56]. This mutation was present in 98\% of the variants present suggesting that this mutation was being selected for in the brain of the sample that was showing clinical symptoms. At this position, histidine was replaced by asparagine (H412N), which may have a consequence on the protein structure as these two amino acids have different properties [57]. Examination of the nucleoprotein structure revealed that this position is exposed, suggesting this change will have an impact on the functionality of the protein. Further, structural prediction of the chain this position is located on reveals that this mutation destabilizes the protein $(\Delta \Delta \mathrm{G}=-1.96)$, indicating that this mutation may have an effect on the pathogenicity of RRV. Evaluation of nucleoprotein sequences in all raccoons where viral RNA was detected, revealed that this mutation was only present in samples that showed clinical symptoms at 20 - 24 days post inoculation. As such, these data suggest this mutation provides the virus with an advantage to establish an infection in the brain. Although results of this study suggest that mutation at position 412 may be a molecular determinant for pathogenicity of RRV in raccoons, future studies should examine the x-ray crystal structure of the virus with the 
mutation to assess the stability of the virus and the functional consequence of this mutation.

\section{Conclusion}

To the best of our knowledge, this is the first study examining expression patterns and viral genetics of a wild rabies virus variant in its natural reservoir. Examination of viral expression both temporally and spatially, enhances our understanding of the behaviour of the virus after peripheral infection; it also provides insight into the replication strategies that the virus employs to establish a successful infection such as restriction of the glycoprotein expression. Similar to Srithayakumar et al. [14], this study shows that the initiation of the immune response after the virus enters the CNS is not sufficient to control it, as the replication of the virus increases significantly upon entry into the CNS. The majority of studies to date examine only nucleoprotein and glycoprotein to elucidate pathogenic determinants of the virus, whereas we examined the entire genome of the RRV to better understand the role of viral genetics on the virulence. Examination of the quasispecies provides insight into the variants present in the brain of an infected raccoon, however, further studies examining quasispecies at different points of the infections will shed light on the variants that may be advantageous at different stages of infection. The lack of similarity between our study and previous studies describing molecular determinants of pathogenicity using mouse models, highlight the need to perform research on natural reservoirs of rabies. Overall, these data contribute to enhancing our knowledge of the molecular mechanisms involved in RRV virulence, and therefore may aid in the development of additional safe, efficacious rabies vaccines to prevent fatal disease.

\section{Acknowledgements}

We would like to thank Drs. B. White and B. Saville for their helpful suggestions and support of this project. We acknowledge the invaluable help of staff of the Canadian Food Inspection Agency Centre of Expertise for Rabies for performance of the challenge study, the collection of tissues from the animals, and the permission to use these samples for the current study. We thank Dr. Annamaria Szanto for RNA preparation from all tissues. We would also like to thank members of the Saville lab for their assistance with RNA work. This project occurred in collaboration with the Rabies Research Unit of the Ontario Ministry of Natural Resources. This research was funded through a NSERC grant to CJK; OGS to VS; OMNR Summer Student Program for HS.

\section{References}

[1] Bouhy, H., Sureau, P. and Tordo, N. (1990) From Rabies to Rabies-Related Viruses. Veterinary Microbiology, 23, 115128. http://dx.doi.org/10.1016/0378-1135(90)90141-H

[2] Tordo, N., Poch, O., Ermine, A., Keith, G. and Rougeon, F. (1988) Completion of the Rabies Virus Genome Sequence Determination: Highly Conserved Domains among the L (Polymerase) Proteins of Unsegmented Negative-Strand RNA Viruses. Virology, 165, 565-576. http://dx.doi.org/10.1016/0042-6822(88)90600-9

[3] Rosatte, R.C. (2011) Evolution of Wildlife Rabies Control Tactics. Advances in Viral Research, 79, 397-419.

[4] Rosatte, R.C. (2013) Rabies Control in Wild Carnivores. In: Jackson, A., Ed., Rabies: Scientific Basis of the Disease and Its Management, Academic Press, Oxford, 617-670. http://dx.doi.org/10.1016/B978-0-12-396547-9.00018-3

[5] World Health Organization (2005) Press Release 2005.

[6] Jackson, A.C. (2013) Rabies: Scientific Basis of the Disease and Its Management. Academic Press, Oxford.

[7] Tsiang, H., La Porte, S., Derer, M., Koenig, J. and Ambroise, D.J. (1986) Infection of Cultured Rat Myotubes and Neurons from the Spinal Cord by Rabies Virus. Journal of Neuropathology \& Experimental Neurology, 45, $28-42$. http://dx.doi.org/10.1097/00005072-198601000-00003

[8] Shankar, V., Dietzschold, B. and Koprowski, H. (1991) Direct Entry of Rabies Virus into the Central Nervous System without Prior Local Replication. Journal of Virology, 65, 2736-2738.

[9] Prosniak, M., Dietzschold, B., Koprowski, H. and Hooper, D.C. (2001) Effect of Rabies Virus Infection on Gene Expression in Mouse Brain. Proceedings of the National Academy of Sciences of the United States of America, 98, 27582763. http://dx.doi.org/10.1073/pnas.051630298

[10] Jackson, A.C. and Reimer, D.L. (1989) Pathogenesis of Experimental Rabies in Mice: An Immunohistochemical Study. Acta Neuropathologica, 78, 159-165. http://dx.doi.org/10.1007/BF00688204

[11] Johnson, N., McKimmie, C.S., Mansfield, K.L., Wakeley, P.R., Brookes, S.M., Fazakerley, J.K. and Fooks, A.R. (2006) Lyssavirus Infection Activates Interferon Gene Expression in the Brain. Journal of General Virology, 87, 2663- 2667. http://dx.doi.org/10.1099/vir.0.82024-0 
[12] Mansfield, K.L., Johnson, N., Nuñez, A., Hicks, D., Jackson, A.C. and Fooks, A.R. (2008) Up-Regulation of Chemokine Gene Transcripts and T-Cell Infiltration into the Central Nervous System and Dorsal Root Ganglia Are Characteristics of Experimental European Bat Lyssavirus Type 2 Infection of Mice. Journal of NeuroVirology, 14, 218-228. http://dx.doi.org/10.1080/13550280802008297

[13] Zhao, P., Zhao, L., Zhang, T., Qi, Y., Wang, T., Liu, K., Wang, H., Feng, H., Jin, H., et al. (2011) Innate Immune Response Gene Expression Profiles in Central Nervous System of Mice Infected with Rabies Virus. Comparative Immunology, Microbiology and Infectious Diseases, 34, 503-512. http://dx.doi.org/10.1016/j.cimid.2011.09.003

[14] Srithayakumar, V., Sribalachandran, H., Rosatte, R., Nadin-Davis, S. and Kyle, C.J. (2014) Innate Immune Responses in Raccoons after Raccoon Rabies Virus Infection. Journal of General Virology, 95, 16-25. http://dx.doi.org/10.1099/vir.0.053942-0

[15] Dietzschold, B., Wunner, W.H., Wiktor, T.J., Lopes, A.D., Lafon, M., Smith, C.L. and Koprowski, H. (1983) Characterization of an Antigenic Determinant of the Glycoprotein that Correlates with Pathogenicity of Rabies Virus. Proceedings of the National Academy of Sciences of the United States of America, 80, 70-74. http://dx.doi.org/10.1073/pnas.80.1.70

[16] Seif, I., Coulon, P., Rollin, P.E. and Flamand, A. (1985) Rabies Virulence: Effect on Pathogenicity and Sequence Characterization of Rabies Virus Mutations Affecting Antigenic Site-III of the Glycoprotein. Journal of Virology, 53, 926-934.

[17] Morimoto, K., Foley, H.D., McGettigan, J.P., Schnell, M.J. and Dietzschold, B. (2000) Reinvestigation of the Role of the Rabies Virus Glycoprotein in Viral Pathogenesis Using a Reverse Genetics Approach. Journal of Neurovirology, 6, 373-381. http://dx.doi.org/10.3109/13550280009018301

[18] Morimoto, K., Hooper, D.C., Spitsin, S., Koprowski, H. and Dietzschold, B. (1999) Pathogenicity of Different Rabies Virus Variants Inversely Correlates with Apoptosis and Rabies Virus Glycoprotein Expression in Infected Primary Neuron Cultures. Journal of Virology, 73, 510-518.

[19] Ito, N., Takayama, M., Yamada, K., Sugiyama, M. and Minamoto, N. (2001) Rescue of Rabies Virus from Cloned cDNA and Identification of the Pathogenicity-Related Gene: Glycoprotein Gene Is Associated with Virulence for Adult Mice. Journal of Virology, 75, 9121-9128. http://dx.doi.org/10.1128/JVI.75.19.9121-9128.2001

[20] Prehaud, C., Lay, S., Dietzschold, B. and Lafon, M. (2003) Glycoprotein of Nonpathogenic Rabies Viruses Is a Key Determinant of Human Cell Apoptosis. Journal of Virology, 77, 10537-10547. http://dx.doi.org/10.1128/JVI.77.19.10537-10547.2003

[21] Takayama-Ito, M., Ito, N., Yamada, K., Sugiyama, M. and Minamoto, N. (2006) Multiple Amino Acids in the Glycoprotein of Rabies Virus Are Responsible for Pathogenicity in Adult Mice. Virus Research, 115, 169-175. http://dx.doi.org/10.1016/j.virusres.2005.08.004

[22] Shimizu, K., Ito, N., Mita, T., Yamada, K., Hosokawa-Muto, J., Sugiyama, M. and Minamoto, N. (2007) Involvement of Nucleoprotein, Phosphoprotein, and Matrix Protein Genes of Rabies Virus in Virulence for Adult Mice. Virus Research, 123, 154-160. http://dx.doi.org/10.1016/j.virusres.2006.08.011

[23] Masatani, T., Ito, N., Shimizu, K., Ito, Y., Nakagawa, K., Abe, M., Yamaoka, S. and Sugiyama, M. (2011) Amino Acids at Positions 273 and 394 in Rabies Virus Nucleoprotein Are Important for both Evasion of Host RIG-I-Mediated Antiviral Response and Pathogenicity. Virus Research, 155, 168-174. http://dx.doi.org/10.1016/j.virusres.2010.09.016

[24] Ito, N., Mita, T., Shimizu, K., Ito, Y., Masatani, T., Nakagawa, K., Yamaoka, S., Abe, M., Okadera, K., Minamoto, N. and Sugiyama, M. (2011) Amino Acid Substitution at Position 95 in Rabies Virus Matrix Protein Affects Viral Pathogenicity. Journal of Veterinary Medical Science, 73, 1363-1366. http://dx.doi.org/10.1292/jvms.11-0151

[25] Jackson, A.C. and Wunner, W.H. (2007) Rabies. 2nd Edition, Academic Press, San Diego.

[26] Coulon, P., Ternaux, J.P., Flamand, A. and Tuffereau, C. (1998) An Avirulent Mutant of Rabies Virus Is Unable to Infect Motoneurons in Vivo and in Vitro. Journal of Virology, 72, 273-278.

[27] Biek, R., Henderson, J.C., Waller, L.A., Rupprecht, C.E. and Real, L.A. (2007) A High-Resolution Genetic Signature of Demographic and Spatial Expansion in Epizootic Rabies Virus. Proceedings of the National Academy of Sciences of the United States of America, 104, 7993-7998. http://dx.doi.org/10.1073/pnas.0700741104

[28] Totton, S., Tinline, R., Rosatte, R. and Bigler, L. (2002) Contact Rates of Raccoons (Procyon lotor) at a Communal Feeding Site in Rural Eastern Ontario. Journal of Wildlife Diseases, 38, 313-319.

http://dx.doi.org/10.7589/0090-3558-38.2.313

[29] Hadidian, J., Prange, S., Rosatte, R., Riley, S. and Gehrt, S. (2010) Raccoons (Procyon lotor). In: Gehrt, S., Riley, S. and Cypher, B., Eds., Urban Carnivores, Ecology, Conflict and Conservation, The Johns Hopkins University Press, Baltimore, 35-48.

[30] Rosatte, R., Sobey, K., Donovan, D., Bruce, L., Allan, M., Silver, A., et al. (2006) Behaviour, Movements, and Demographics of Rabid Raccoons in Ontario, Canada: Management Implications. Journal of Wildife Diseases, 42, 589-605. http://dx.doi.org/10.7589/0090-3558-42.3.589 
[31] Carey, A. and McLean, R. (1983) The Ecology of Rabies: Evidence of Co-Adaptation. Journal of Applied Ecology, 20, 777-800. http://dx.doi.org/10.2307/2403126

[32] Szanto, A. (2009) Molecular Genetics of the Raccoon Rabies Virus. Doctoral Dissertation, Trent University, Peterborough.

[33] Knowles, Personal Communication.

[34] Rupprecht, C.E., Koprowski, H., Hamir, A.N. and Johnston, D.H. (1988) Efficacy of a Vaccinia-Rabies Glycoprotein Recombinant Virus Vaccine in Raccoons (Procyon lotor). Clinical Infectious Diseases, 10, S803-S809. http://dx.doi.org/10.1093/clinids/10.Supplement_4.S803

[35] Brown, L., Rosatte, R., Fehlner-Gardiner, C., Taylor, S., Davies, J. and Donovan, D. (2012) Immune Response and Protection in Raccoons (Procyon lotor) Following Consumption of Baits Containing ONRAB, a Human Adenovirus Rabies Glycoprotein Recombinant Vaccine. Journal of Wildlife Diseases, 48, 1010-1020. http://dx.doi.org/10.7589/2012-01-023

[36] Schmittgen, T. and Livak, K. (2008) Analyzing Real-Time PCR Data by the Comparative $\mathrm{C}_{\mathrm{T}}$ Method. Nature Protocols, 3, 1101-1108. http://dx.doi.org/10.1038/nprot.2008.73

[37] Tamura, K., Dudley, J., Nei, M. and Kumar, S. (2007) MEGA4: Molecular Evolutionary Genetics Analysis (MEGA) Software Version 4.0. Molecular Biology and Evolution, 24, 1596-1599. http://dx.doi.org/10.1093/molbev/msm092

[38] Arnold, K., Bordoli, L., Kopp, J. and Schwede, T. (2006) The SWISS-MODEL Workspace: A Web-Based Environment for Protein Structure Homology Modelling. Bioinformatics, 22, 195-201. http://dx.doi.org/10.1093/bioinformatics/bti770

[39] Kiefer, F., Arnold, K., Kuenzli, M., Bordoli, L. and Schwede, T. (2009) The SWISS-MODEL Repository and Associated Resources. Nucleic Acids Research, 37, D387-D392. http://dx.doi.org/10.1093/nar/gkn750

[40] Worth, C.L., Preissner, R. and Blundell, T.L. (2011) SDM-A Server for Predicting Effects of Mutations on Protein Stability and Malfunction. Nucleic Acids Research, 39, W215-W222. http://dx.doi.org/10.1093/nar/gkr363

[41] Rupprecht, C.E., Smith, J.S., Fekadu, M. and Childs, J.E. (1995) The Ascension of Wildlife Rabies-A Cause for Public-Health Concern or Intervention. Emerging Infectious Diseases, 1, 107-114.

[42] Brzozka, K., Finke, S. and Conzelmann, K. (2006) Inhibition of Interferon Signaling by Rabies Virus Phosphoprotein P: Activation-Dependent Binding of STAT1 and STAT2. Journal of Virology, 80, 2675-2683. http://dx.doi.org/10.1128/JVI.80.6.2675-2683.2006

[43] ChelbiAlix, M., Vidy, A., El Bougrini, J. and Blondel, D. (2006) Rabies Viral Mechanisms to Escape the IFN System: The Viral Protein P Interferes with IRF-3, Stat1, and PML Nuclear Bodies. Journal of Interferon \& Cytokine Research, 26, 271-280. http://dx.doi.org/10.1089/jir.2006.26.271

[44] Wirblich, C. and Schnell, M.J. (2011) Rabies Virus (RV) Glycoprotein Expression Levels Are Not Critical for Pathogenicity of RV. Journal of Virology, 85, 697-704. http://dx.doi.org/10.1128/JVI.01309-10

[45] Faber, M., Pulmanausahakul, R., Hodawadekar, S.S., Spitsin, S., McGettigan, J.P., Schnell, M.J. and Dietzschold, B. (2002) Overexpression of the Rabies Virus Glycoprotein Results in Enhancement of Apoptosis and Antiviral Immune Response. Journal of Virology, 76, 3374-3381. http://dx.doi.org/10.1128/JVI.76.7.3374-3381.2002

[46] Faber, M., Pulmanausahakul, R., Nagao, K., Prosniak, M., Rice, A.B., Koprowski, H., Schnell, M.J. and Dietzschold, B. (2004) Identification of Viral Genomic Elements Responsible for Rabies Virus Neuroinvasiveness. Proceedings of the National Academy of Sciences of the United States of America, 101, 16328-16332. http://dx.doi.org/10.1073/pnas.0407289101

[47] Wang, Z.W., Sarmento, L., Wang, Y., Li, X., Dhingra, V., Tseggai, T., Jiang, B. and Fu, Z.F. (2005) Attenuated Rabies Virus Activates, While Pathogenic Rabies Virus Evades, the Host Innate Immune Responses in the Central Nervous System. Journal of Virology, 79, 12554-12565. http://dx.doi.org/10.1128/JVI.79.19.12554-12565.2005

[48] Holland, J.J., Delatorre, J.C. and Steinhauer, D.A. (1992) RNA Virus Populations as Quasi-Species. Current Topics in Microbiology and Immunology, 176, 1-20. http://dx.doi.org/10.1007/978-3-642-77011-1_1

[49] Domingo, E. and Holland, J.J. (1997) RNA Virus Mutations and Fitness for Survival. Annual Review of Microbiology, 51, 151-178. http://dx.doi.org/10.1146/annurev.micro.51.1.151

[50] Smith, D.B., McAllister, J., Casino, C. and Simmonds, P. (1997) Virus “Quasispecies”: Making a Mountain out of a Molehill? Journal of General Virology, 78, 1511-1519.

[51] Khawplod, P., Shoji, Y., Ubol, S., Mitmoonpitak, C., Wilde, H., Nishizono, A., Kurane, I. and Morimoto, K. (2006) Genetic Analysis of Dog Rabies Viruses Circulating in Bangkok. Infection, Genetics and Evolution, 6, 235-240. http://dx.doi.org/10.1016/j.meegid.2005.06.002

[52] Vignuzzi, M., Stone, J.K., Arnold, J.J., Cameron, C.E. and Andino, R. (2006) Quasispecies Diversity Determines Pathogenesis through Cooperative Interactions in a Viral Population. Nature, 439, 344-348.

http://dx.doi.org/10.1038/nature04388 
[53] Crotty, S., Cameron, C.E. and Andino, R. (2001) RNA Virus Error Catastrophe: Direct Molecular Test by Using Ribavirin. Proceedings of the National Academy of Sciences of the United States of America, 98, 6895-6900. http://dx.doi.org/10.1073/pnas.111085598

[54] Fu, Z.F., Wunner, W.H. and Dietzschold, B. (1994) Immunoprotection by Rabies Virus Nucleoprotein. Current Topics in Microbiology and Immunology, 187, 161-172. http://dx.doi.org/10.1007/978-3-642-78490-3_9

[55] Minamoto, N., Tanaka, H., Hishida, M., Goto, H., Ito, H., Naruse, S., Yamamoto, K., Sugiyama, M., Kinjo, T., Mannen, K. and Mifune, K. (1994) Linear and Conformation-Dependent Antigenic Sites on the Nucleoprotein of Rabies Virus. Microbiology and Immunology, 38, 449-455. http://dx.doi.org/10.1111/j.1348-0421.1994.tb01806.x

[56] Goto, H., Minamoto, N., Ito, H., Ito, N., Sugiyama, M., Kinjo, T. and Kawai, A. (2000) Mapping of Epitopes and Structural Analysis of Antigenic Sites in the Nucleoprotein of Rabies Virus. Journal of General Virology, 81, 119-127.

[57] Betts, M.J. and Russell, R.B. (2003) Amino Acid Properties and Consequences of Substitutions. In: Barnes, M.R., Ed., Bioinformatics for Geneticists, Ch. 14, John Wiley \& Sons Ltd., West Sussex, 289-316. 
Scientific Research Publishing (SCIRP) is one of the largest Open Access journal publishers. It is currently publishing more than 200 open access, online, peer-reviewed journals covering a wide range of academic disciplines. SCIRP serves the worldwide academic communities and contributes to the progress and application of science with its publication.

Other selected journals from SCIRP are listed as below. Submit your manuscript to us via either submit@scirp.org or Online Submission Portal.
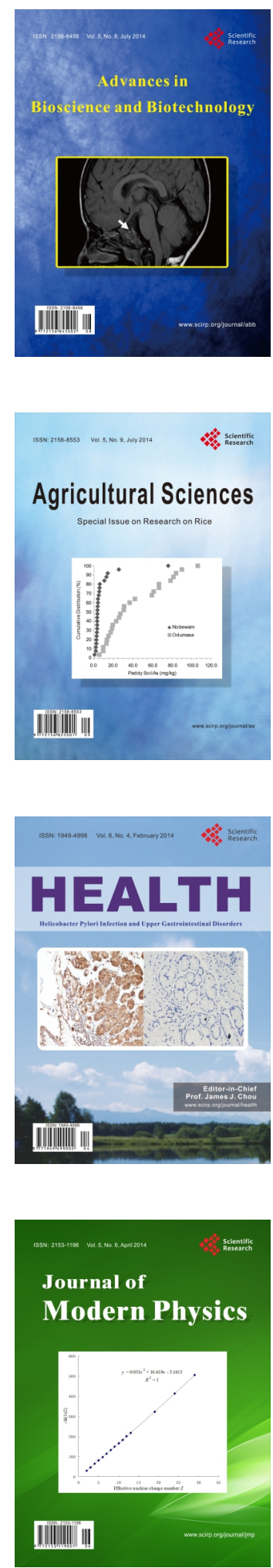
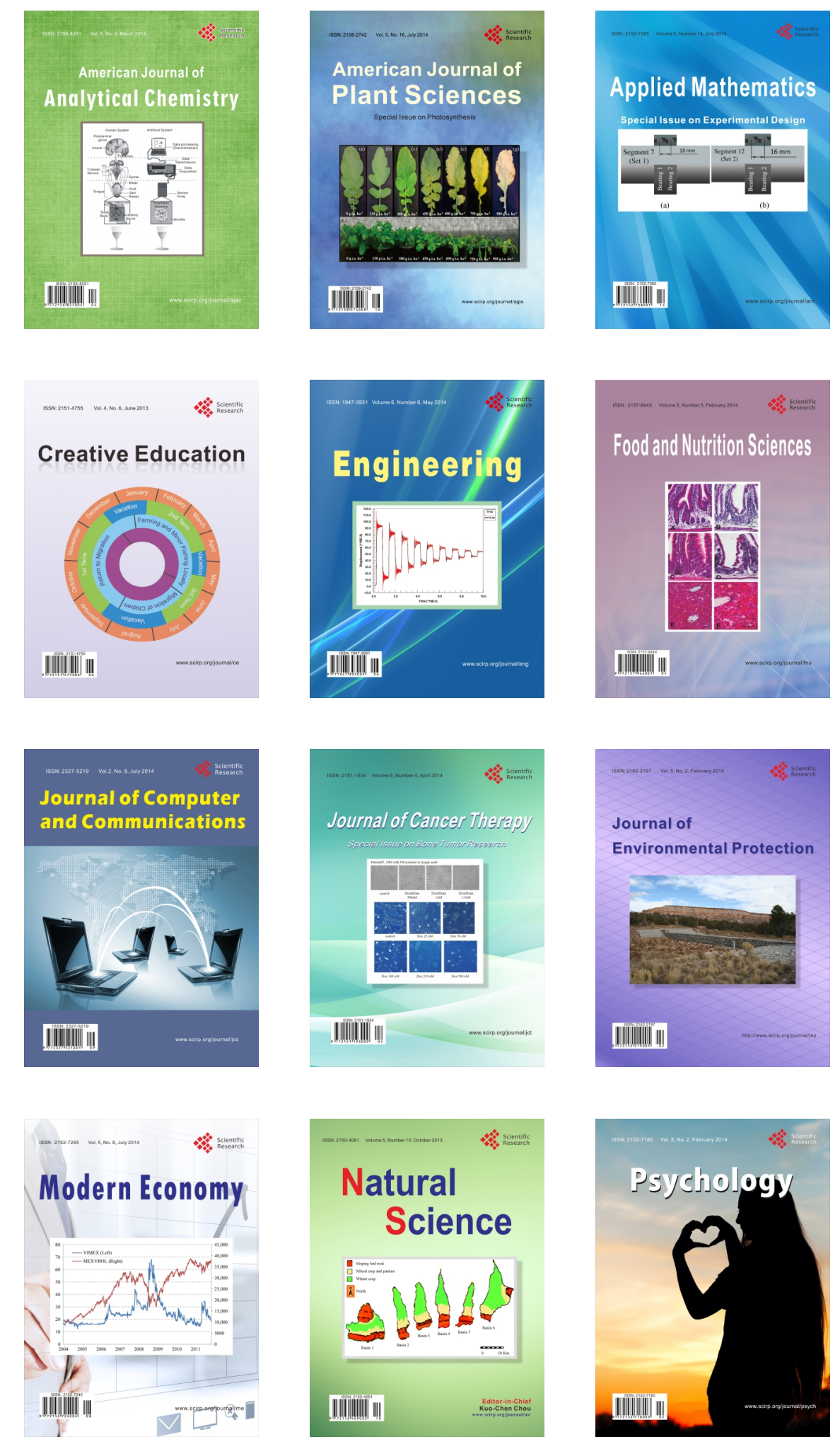